\title{
GMR
}

\section{Immunohistochemical localization of sex hormone receptors in two Raillietina tapeworms}

\author{
L. Chen ${ }^{1,2,3}$, Y.M. Sun ${ }^{2}$, L. Mu², Y. Zeng ${ }^{2}$, H.Y. Li' ${ }^{2}$ and T.H. Yang ${ }^{3}$ \\ ${ }^{1}$ School of Medicine, Kunming University of Science and Technology, \\ Kunming, Yunnan, China \\ ${ }^{2}$ Department of Aquiculture, College of Animal Science, \\ South China Agricultural University, Guangzhou, China \\ ${ }^{3}$ Department of Hematology, the First People's Hospital of Yunnan Province, \\ Kunming University of Science and Technology, Kunming, China \\ Corresponding authors: H.Y. Li / T.H. Yang \\ E-mail: 1377593984@qq.com
}

Genet. Mol. Res. 16 (1): gmr16019033

Received July 26, 2016

Accepted January 27, 2017

Published March 8, 2017

DOI http://dx.doi.org/10.4238/gmr16019033

Copyright $(C 2017$ The Authors. This is an open-access article distributed under the terms of the Creative Commons Attribution ShareAlike (CC BY-SA) 4.0 License.

\begin{abstract}
Sex hormone receptors play critical roles in development and reproduction. However, it is not known whether they exist in Raillietina tapeworms, and if they do, whether they have a similar function to that in vertebrates. We examined the immunohistochemical distributions of androgen receptors (ARs), estrogen receptors (ERs), and progesterone receptors (PRs) in the tissues of two tapeworm species: Raillietina echinobothrida and Raillietina tetragona. Immunopositive ARs were found in the entire reproductive system of $R$. echinobothrida, including the testes, ovaries, and oocysts, and weakly immunopositive ERs and PRs were found in the testes, ovaries, and oocysts. Immunopositive ARs were also found throughout the entire reproductive system of $R$. tetragona, including the testes, ovaries, and oocysts, and weakly immunopositive ERs were in the testes and oocysts; the PRs were distributed in an immunonegative manner. The results show that androgens and their receptors play critical roles in reproductive system development in the two tapeworms. The immunoreactivity and
\end{abstract}

Genetics and Molecular Research 16 (1): gmr16019033 
tissue localizations of the sex hormone receptors suggest that, in both species, they have similar functions as in vertebrates, and modulate reproduction.

Key words: Raillietina echinobothrida; Raillietina tetragona; Sex hormone receptor; Immunolocalization

\section{INTRODUCTION}

Sex hormone receptors play critical roles during both development and reproduction. Studies on sex hormone receptors have mainly focused on vertebrates (Fannon et al., 2001; González-Morán et al., 2008; Cleve et al., 2012; Wang et al., 2014; Fu et al., 2016); however, the number of studies that have investigated sex hormone receptors in invertebrates has increased in the last 20 years, before which it was believed that these receptors originated from deuterostome (Laudet et al., 1992). These receptor families are more ancient than previously thought (Thornton et al., 2003). Gagné and Blaise (2003) detected estrogen receptors (ERs) in the homogenate of freshwater Elliptio complanata, and ER-like immunoreactivity has been found in growing oocytes and auxiliary cells in close contact with the growing oocytes of the scallop Patinopecten yessoensis (Osada et al., 2003). Furthermore, Di Cosmo et al. (2002) identified a $17 \beta$-estradiol receptor in the reproductive system of female Octopus vulgaris, which had characteristics that resembled those of ERs in vertebrates (high affinity, specificity, and immunoreactivity). Moreover, a hormone-activated estrogen receptor has been found in the annelids Platynereis dumerilii and Capitella capitata (Keay and Thornton, 2009). Androgen receptors (ARs) and progesterone receptors (PRs) have also been identified in invertebrates (de Mendonça et al., 2000; Escobedo et al., 2010).

Tapeworms are platyhelminths, which played an important role in animal evolution (Králová-Hromadová et al., 2013; Yan et al., 2013). Regarding tapeworms, testosterone and $17 \beta$-estradiol have been found in Taenia solium and T. crassiceps cysticerci (Romano et al., 2003; Valdéz et al., 2006). In addition, androgen and progesterone have also been identified in the tissue homogenate of $R$. tetragona (Sun et al., 2010), and many key enzymes in the sex hormone biosynthesis pathway have been identified in tapeworms (Valdéz et al., 2006; Janer and Porte, 2007). Sex hormones perform their biological functions by binding to their receptors in vertebrates (Fannon et al., 2001). However, it is not known whether sex hormone receptors exist in Raillietina tapeworms. Therefore, we followed an immunohistochemical approach to detect ARs, ERs, and PRs in the tissues of two tapeworms, $R$. echinobothrida and $R$. tetragona.

\section{MATERIAL AND METHODS}

\section{Tapeworms}

Adult R. echinobothrida and R. tetragona tapeworms were obtained from the intestines of 106 chickens that were bought at Sanjiao Market, South China Agriculture University, China. After being washed and dissected, the intestines were doused with $\mathrm{ddH}_{2} \mathrm{O}$ once the tapeworms were discovered. The tapeworms were removed after their scolexes had been anesthetized by $\mathrm{ddH}_{2} \mathrm{O}$ and disjunct from intestine wall. After being rinsed several times with physiological saline, the tapeworms were fixed in 10\% neutron-formalin for 8-24 h to maintain their natural state.

Genetics and Molecular Research 16 (1): gmr16019033 


\section{Chemicals and reagents}

Mouse monoclonal antibody against ARs (110 kDa, clone No. AR441), rabbit monoclonal antibody against ERs (66 kDa, a synthetic peptide corresponding to residues near the N-terminus of the human estrogen receptor), and rabbit monoclonal antibody against PRs (clone No. Y85, a synthetic peptide corresponding to residues near the N-terminus of the progesterone receptor) were obtained from Epitomics ${ }^{\circledR}$. None of the antibodies crossreacted with the other two steroid hormone receptors. A SuperMark polymer-HRP kit (Ascend Biotechnology Co. Ltd., China) was used as a second antibody. The following buffers were used: $0.01 \mathrm{M}$ citrate buffer solution, $\mathrm{pH}$ 6.0, and $0.01 \mathrm{M}$ phosphate buffer solution, $\mathrm{pH}$ 7.4. The phosphate buffer solution was used as a negative control.

\section{Paraffin section}

The fixed samples were cut into small pieces (approximately 1-1.5 cm). The materials then underwent gradual alcoholic dehydration, paraffin imbedding, and serial sectioning (5$\mu \mathrm{m}$ thickness). After adhesion, the sections were baked at $37^{\circ} \mathrm{C}$ overnight.

\section{Immunohistochemistry}

The immunolocalization procedure was similar to that used previously (Brattig et al., 2010; Kueakhai et al., 2011), with some modifications. Deparaffinated section slides were placed in $0.01 \mathrm{M}$ citrate buffer solution, $\mathrm{pH}$ 6.0, and incubated for $10 \mathrm{~min}$ in a microwave. Slides were then incubated in $3 \% \mathrm{H}_{2} \mathrm{O}_{2}$ for $10 \mathrm{~min}$ to block endogenous peroxidase. Antibodies against ARs, ERs, and PRs were incubated for $1 \mathrm{~h}$ at $25^{\circ} \mathrm{C}$, or at $4^{\circ} \mathrm{C}$ overnight. Phosphatebuffered saline was used as a negative control. The paraffin sections were incubated with polymer-HRP biotin-free general-style second antibodies (SuperMark) for $20-30 \mathrm{~min}$ at $25^{\circ} \mathrm{C}$. They were then reacted with Diaminobenzidine (DAB) for 1-2 min to colorate, dyed with haematoxylin for 1-2 min, and rinsed with water to remove the superfluous dye. The slides were subsequently dehydrated and mounted on neutral resin. A Leica DM2500 microscope was used to observe the slides and take photographs (Leica Microsystems, Wetzlar, Germany).

\section{RESULTS}

Three $R$. echinobothrida tapeworms and five R. tetragona tapeworms were found, with a total infection rate of $7.5 \%$.

\section{Distribution of sex hormone receptors in male reproductive organs}

In $R$. echinobothrida, strongly immunopositive ARs were found in the testes of mature proglottids, and parenchymatous tissues and teguments were also stained with anti-AR antibodies (Figure 1A). Immunopositive ERs were in the testes; however, the PR reaction was weak (Figure $1 \mathrm{C}$ and $\mathrm{E}$ ). In $R$. tetragona, ARs had a wide distribution; besides the testes, they were also present in the parenchymatous tissues and teguments (Figure 1B). The ERs exhibited a weak immunopositive reaction, and there were no PRs present (Figure 1D and F). 


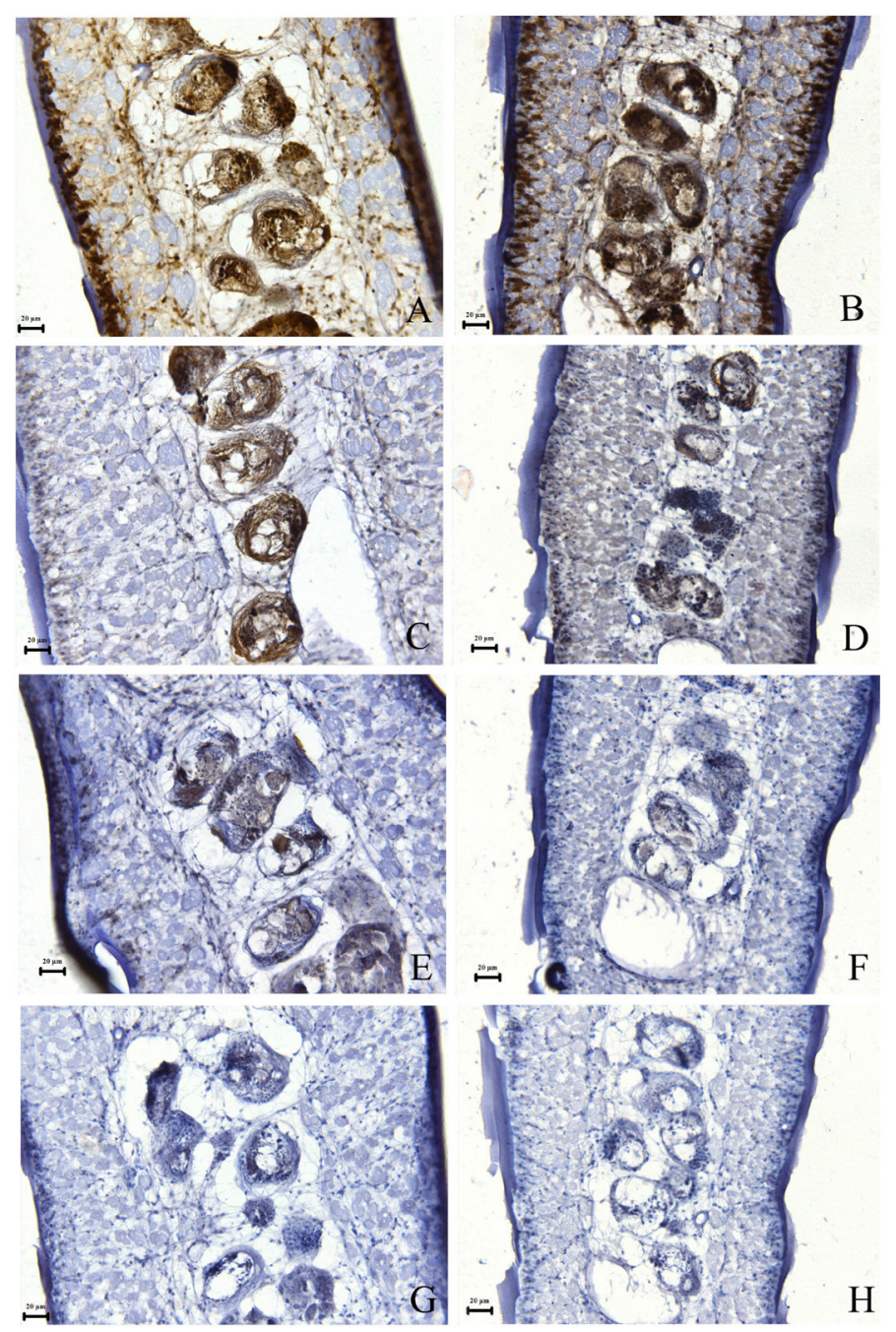

Figure 1. Distribution of sex hormone receptors in the testes of Raillietina echinobothrida and Raillietina tetragona. Immunopositive androgen receptors were found in the testes, parenchymatous tissues, and teguments of both $R$. echinobothrida (A) and $R$. tetragona $(\mathbf{B}) ;(\mathbf{C})$ immunopositive estrogen receptors (ERs) in the testes of $R$. echinobothrida; (D) immunopositive ERs in the testes and teguments of R. tetragona; (E) weakly immunopositive progesterone receptors (PRs) in the testes of $R$. echinobothrida; (F) immunonegative PRs in R. tetragona; $(\mathbf{G})$ and (H) were controls for R. echinobothrida and R. tetragona, respectively. Scale bars (A-H) $=20 \mu \mathrm{m}$.

\section{Distribution of sex hormone receptors in female reproductive organs}

Immunopositive ARs were in the ovaries, vitellaria, and parenchymatous tissues of R. echinobothrida (Figure 2A), while the ERs and PRs only had weakly immunopositive reactions in the ovaries (Figure $2 \mathrm{C}$ and $\mathrm{E}$ ). In $R$. tetragona, AR-immunopositive reactions were found in the ovaries (Figure 2B); neither ERs nor PRs were found (Figure 2D and F). 


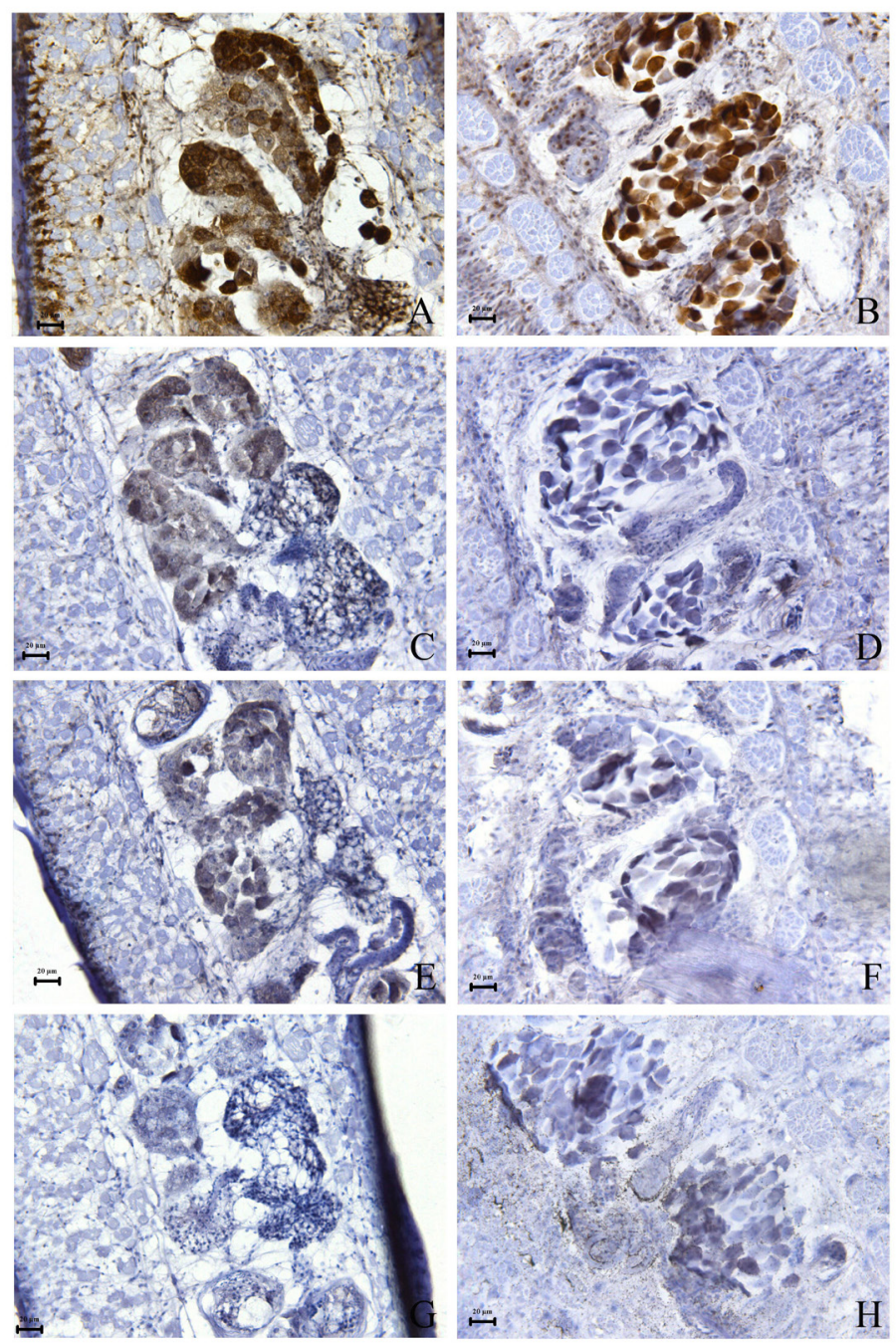

Figure 2. Distribution of sex hormone receptors in the ovaries of Raillietina echinobothrida and Raillietina tetragona. (A) Immunopositive androgen receptors (ARs) in the ovaries and teguments of R. echinobothrida; (B) immunopositive ARs in the ovaries of $R$. tetragona; (C) weakly immunopositive estrogen receptors (ERs) in the ovaries of R. echinobothrida; (D) no ERs were found in the ovaries of $R$. tetragona; (E) weakly immunopositive progesterone receptors (PRs) in the ovaries of R. echinobothrida; $(\mathbf{F})$ immunonegative PRs in R. tetragona; $(\mathbf{G})$ and (H) were controls for $R$. echinobothrida and $R$. tetragona, respectively. Scale bars (A-H) $=20 \mu \mathrm{m}$.

\section{Distribution of sex hormone receptors in gravid proglottids}

Immunopositive ARs were present in the eggs of $R$. echinobothrida, and egg capsules that were surrounded by parenchymatous tissue were also stained with anti-AR antibodies (Figure 3A). Both ERs and PRs were found in the eggs and egg capsules of R. echinobothrida (Figure $3 \mathrm{C}$ and $\mathrm{E}$ ). In $R$. tetragona eggs, ARs had immunopositive reactions (Figure 3B), and ERs had weak immunopositive reactions (Figure 3D); however, there were no PRs (Figure 3F). 


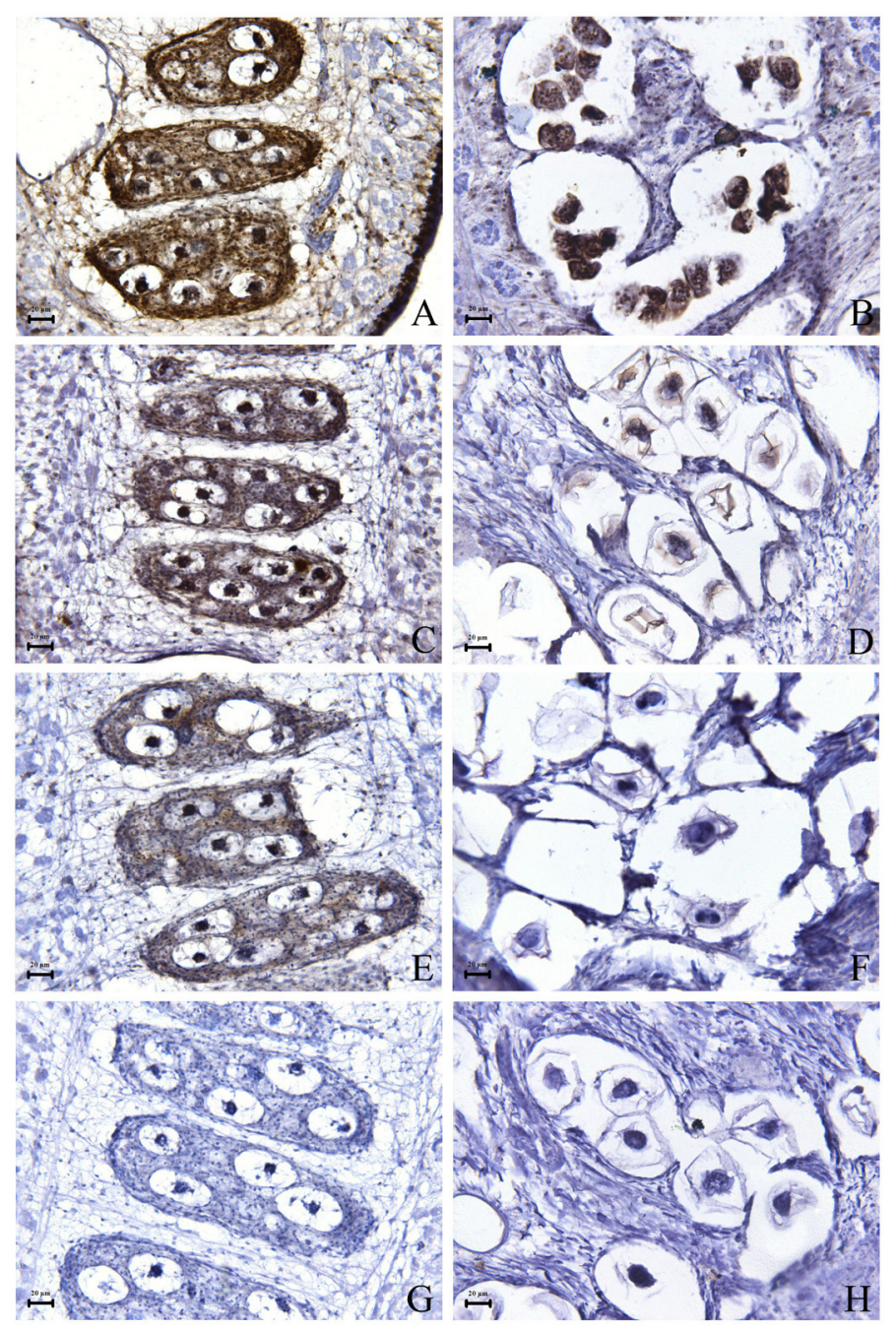

Figure 3. Distribution of sex hormone receptors in the gravid proglottids of Raillietina echinobothrida and Raillietina tetragona. (A) Immunopositive androgen receptors (ARs) were found in the eggs, egg capsules, and teguments of $R$. echinobothrida; (B) immunopositive ARs in the eggs of $R$. tetragona; $(\mathbf{C})$ immunopositive estrogen receptors (ERs) in the eggs and egg capsules of R. echinobothrida; (D) weakly immunopositive ERs in the eggs of R. tetragona; (E) immunopositive progesterone receptors (PRs) in the eggs and egg capsules of $R$. echinobothrida; (F) immunonegative PRs in R. tetragona; $(\mathbf{G})$ and $(\mathbf{H})$ were controls for $R$. echinobothrida and $R$. tetragona, respectively. Scale bars $(\mathrm{A}-\mathrm{H})=20 \mu \mathrm{m}$.

\section{DISCUSSION}

Sex hormones and their receptors widely exist in vertebrates, and play an important role in the processes of development and reproduction. Sex hormones corresponding to those in vertebrates have been reported in several invertebrates, particularly in arthropods and 
mollusks (Janer and Porte, 2007; Morris and Spradling, 2012; Zhang et al., 2012). Regarding tapeworms, there is evidences that testosterone and estrogen are present in the cysticerci of T. solium and T. crassiceps (Romano et al., 2003; Valdéz et al., 2006). The cysticerci can synthesis androgens using progesterone as a precursor (Jiménez et al., 2006). Sun et al. (2010) found testosterone and progesterone in the tissues of $R$. tetragona. In the present study, we found ARs, ERs, and PRs in the tissues (although not in the same tissue) of R. echinobothrida and $R$. tetragona. However, whether sex hormone receptors behave in the same way as in vertebrates during tapeworm development and reproduction requires further investigation.

Escobedo et al. (2004) found that $17 \beta$-estradiol and progesterone could stimulate the reproduction and infectivity of $T$. crassiceps cysticerci. However, testosterone and dihydrotestosterone inhibit their reproduction and reduce their motility and infectivity. $17 \beta$-estradiol and progesterone levels increase, whereas testosterone and dihydrotestosterone levels decrease (Escobedo et al., 2004). Schistosomes express a homologous androgen receptor that affects androgen binding (de Mendonça et al., 2000). In the present study, ARs were found in the male and female reproductive systems and gravid proglottids of both tapeworm species, which suggests that androgens and their receptors function throughout the entire developmental stages of the reproductive systems of both tapeworms, including the initial stage, spermary development, ovary development, and fertilization.

Regarding ERs, both $\alpha$ and $\beta$ ER isoforms are expressed in T. crassiceps (Escobedo et al., 2004). We found immunopositive ERs in the testes and eggs of $R$. echinobothrida; however, there were only weakly immunopositive ERs in the ovaries. In the tissues of $R$. tetragona, weakly immunopositive ERs were found in the testes and eggs. Our results are very different from those in vertebrates, in which ERs are abundant in female reproductive organs. Reproductive function mediated by ERs requires a combination of estrogen and its corresponding receptor. However, in the two Raillietina tapeworms there were only weakly immunopositive ERs, suggesting that ERs are not important for tapeworms, at least in the development of the female reproduction system.

Strongly immunopositive PRs were found in the eggs and egg capsules of $R$. echinobothrida; however, only weakly immunopositive PRs were present in the testes and ovaries. No PRs were found in the tissues of $R$. tetragona. It is possible that the antibody against human PR that was used in this study may have had different reaction specifications when recognizing the PRs of the two tapeworms. Escobedo et al. (2004) designed primers for PR-A and PR-B based on the most conserved regions of sequenced PR genes in most of the species in the NIH Gene Data Bank to clone the PRs from T. crassiceps. Their results showed that there was no PR expression (neither isoform A nor B) (Escobedo et al., 2004). However, in another study, a protein (T. solium PR, TsPR) was found that could recognize progesterone and mediate its effects. TsPR only matches to the PR-B isoform (Escobedo et al., 2010). Whether PRs exist in tapeworms requires further investigation, which should involve more species of tapeworm.

In conclusion, we investigated the immunoreactivity and immunolocalization of ARs, ERs, and PRs in $R$. echinobothrida and $R$. tetragona. ARs were expressed throughout the entire development of the reproductive system in both tapeworms, including the male and female reproductive organs and gravid proglottids; however, the expression patterns of ERs and PRs varied greatly between the two species, depending on the tissue type. To the best of our knowledge, this is the first study conducted on the immunolocalization of sex hormone receptors in Raillietina tapeworms. Confirmation of the existence of the sex hormone

Genetics and Molecular Research 16 (1): gmr16019033 
receptors, together with their localizations, would further our understanding of the effects of sex hormone receptors on the development, reproduction, and evolution of platyhelminths. The localization patterns of the different sex hormone receptors and their effects on development and reproduction in tapeworms require further investigation.

\section{Conflicts of interest}

The authors declare no conflict of interest.

\section{ACKNOWLEDGMENTS}

Research supported by the Guangdong Province Natural Science Fund (\#06025794), the National Natural Science Foundation of China (\#81460032), and the Natural Science Research Foundation of Kunming University of Science and Technology (\#KKSY201460068).

\section{REFERENCES}

Brattig NW, Tenner-Racz K, Korten S, Hoerauf A, et al. (2010). Immunohistology of ectopic secondary lymph follicles in subcutaneous nodules from patients with hyperreactive onchocerciasis (sowda). Parasitol. Res. 107: 657-666. http:// dx.doi.org/10.1007/s00436-010-1912-0

Cleve A, Fritzemeier KH, Haendler B, Heinrich N, et al. (2012). Pharmacology and clinical use of sex steroid hormone receptor modulators. Handb. Exp. Pharmacol. 214: 543-587. http://dx.doi.org/10.1007/978-3-642-30726-3 24

de Mendonça RL, Escrivá H, Bouton D, Laudet V, et al. (2000). Hormones and nuclear receptors in schistosome development. Parasitol. Today (Regul. Ed.) 16: 233-240. http://dx.doi.org/10.1016/S0169-4758(00)01641-0

Di Cosmo A, Di Cristo C and Paolucci M (2002). A estradiol-17 $\beta$ receptor in the reproductive system of the female of Octopus vulgaris: characterization and immunolocalization. Mol. Reprod. Dev. 61: 367-375. http://dx.doi. org/10.1002/mrd.10014

Escobedo G, Larralde C, Chavarria A, Cerbón MA, et al. (2004). Molecular mechanisms involved in the differential effects of sex steroids on the reproduction and infectivity of Taenia crassiceps. J. Parasitol. 90: 1235-1244. http:// dx.doi.org/10.1645/GE-297R

Escobedo G, Camacho-Arroyo I, Hernández-Hernández OT, Ostoa-Saloma P, et al. (2010). Progesterone induces scolex evagination of the human parasite Taenia solium: evolutionary implications to the host-parasite relationship. J. Biomed. Biotechnol. 2010: 591079. http://dx.doi.org/10.1155/2010/591079

Fannon SA, Vidaver RM and Marts SA (2001). An abridged history of sex steroid hormone receptor action. J. Appl. Physiol. 91: 1854-1859.

Fu XH, Zhang WQ and Qu XS (2016). Correlation of androgen receptor and SRD5A2 gene mutations with pediatric hypospadias in 46, XY DSD children. Genet. Mol. Res. 15: 15018232. http://dx.doi.org/10.4238/gmr.15018232

Gagné F and Blaise C (2003). Effects of municipal effluents on serotonin and dopamine levels in the freshwater mussel Elliptio complanata. Comp. Biochem. Physiol. C Toxicol. Pharmacol. 136: 117-125. http://dx.doi.org/10.1016/ $\underline{\text { S1532-0456(03)00171-6 }}$

González-Morán MG, Guerra-Araiza C, Campos MG and Camacho-Arroyo I (2008). Histological and sex steroid hormone receptor changes in testes of immature, mature, and aged chickens. Domest. Anim. Endocrinol. 35: 371-379. http:// dx.doi.org/10.1016/j.domaniend.2008.08.001

Janer G and Porte C (2007). Sex steroids and potential mechanisms of non-genomic endocrine disruption in invertebrates. Ecotoxicology 16: 145-160. http://dx.doi.org/10.1007/s10646-006-0110-4

Jiménez P, Valdez RA and Romano MC (2006). Metabolism of steroid hormones by Taenia solium and Taenia crassiceps cysticerci. J. Steroid Biochem. Mol. Biol. 99: 203-208. http://dx.doi.org/10.1016/j.jsbmb.2006.01.002

Keay J and Thornton JW (2009). Hormone-activated estrogen receptors in annelid invertebrates: implications for evolution and endocrine disruption. Endocrinology 150: 1731-1738. http://dx.doi.org/10.1210/en.2008-1338

Králová-Hromadová I, Štefka J, Bazsalovicsová E, Bokorová S, et al. (2013). The tapeworm Atractolytocestus tenuicollis (Cestoda: Caryophyllidea)--a sister species or ancestor of an invasive A. huronensis? Parasitol. Res. 112: 3379-3388. http://dx.doi.org/10.1007/s00436-013-3516-y

Genetics and Molecular Research 16 (1): gmr16019033 
Kueakhai P, Meemon K, Changklungmoa N, Chaithirayanon K, et al. (2011). Characterization and localization of saposinlike protein-2 (SAP-2) in Fasciola gigantica. Parasitol. Res. 108: 1493-1500. http://dx.doi.org/10.1007/s00436-010$\underline{2201-7}$

Laudet V, Hänni C, Coll J, Catzeflis F, et al. (1992). Evolution of the nuclear receptor gene superfamily. EMBO J. 11: 1003-1013.

Morris LX and Spradling AC (2012). Steroid signaling within Drosophila ovarian epithelial cells sex-specifically modulates early germ cell development and meiotic entry. PLoS One 7: e46109. http://dx.doi.org/10.1371/journal. pone.0046109

Osada M, Takamura T, Sato H and Mori K (2003). Vitellogenin synthesis in the ovary of scallop, Patinopecten yessoensis: Control by estradiol-17 $\beta$ and the central nervous system. J. Exp. Zoolog. A Comp. Exp. Biol. 299: 172-179. http:// dx.doi.org/10.1002/jez.a.10276

Romano MC, Valdéz RA, Cartas AL, Gómez Y, et al. (2003). Steroid hormone production by parasites: the case of Taenia crassiceps and Taenia solium cysticerci. J. Steroid Biochem. Mol. Biol. 85: 221-225. http://dx.doi.org/10.1016/ $\underline{\text { S0960-0760(03)00233-4 }}$

Sun Y, Li H and Mu L (2010). Positioning analysis on levels and receptors of sex hormones in Raillietina tetragona. Sichuan Dong Wu 29: 874-877.

Thornton JW, Need E and Crews D (2003). Resurrecting the ancestral steroid receptor: ancient origin of estrogen signaling. Science 301: 1714-1717. http://dx.doi.org/10.1126/science.1086185

Valdéz RA, Jiménez P, Cartas AL, Gómez Y, et al. (2006). Taenia solium cysticerci synthesize androgens and estrogens in vitro. Parasitol. Res. 98: 472-476. http://dx.doi.org/10.1007/s00436-005-0095-6

Wang J, Xu J, Wang B, Shu FR, et al. (2014). Equol promotes rat osteoblast proliferation and differentiation through activating estrogen receptor. Genet. Mol. Res. 13: 5055-5063. http://dx.doi.org/10.4238/2014.July.4.21

Yan H, Lou Z, Li L, Ni X, et al. (2013). The nuclear 18S ribosomal RNA gene as a source of phylogenetic information in the genus Taenia. Parasitol. Res. 112: 1343-1347. http://dx.doi.org/10.1007/s00436-012-3199-9

Zhang H, Pan L and Zhang L (2012). Molecular cloning and characterization of estrogen receptor gene in the scallop Chlamys farreri: expression profiles in response to endocrine disrupting chemicals. Comp. Biochem. Physiol. C Toxicol. Pharmacol. 156: 51-57. http://dx.doi.org/10.1016/j.cbpc.2012.03.007 